\title{
Effects of biological soil crusts and drought on emergence and survival of a Patagonian perennial grass in the Monte of Argentina
}

\author{
Flavia Alejandra FUNK ${ }^{1}$, Alejandro LOYDI ${ }^{1 *}$, Guadalupe PETER ${ }^{2}$ \\ ${ }^{1}$ Center for Renewable Natural Resources of the Semi-arid Zone, National Scientific and Technical Research Council (CONICET), \\ Bahía Blanca 8000, Argentina; \\ ${ }^{2}$ Río Negro National University, Viedma 8500, Argentina
}

\begin{abstract}
Biological soil crusts are widely distributed in arid and semiarid regions. They have an important ecological role, especially by modifying physical and chemical properties of soils. Biological crusts may also modify seed germination and seedling establishment. The effects vary widely according to the type of crust and the vascular plant species. The objective of this study was to determine the effect of moss-dominated biological soil crusts on the emergence, biomass and survival of Poa ligularis Nees ex Steud. under different irrigation regimes. We collected seeds of $P$. ligularis and biological soil crusts composed of two species of mosses: Syntrichia princeps (De Not.) Mitt and Ceratodon purpureus (Hedw.) Brid. from an area in the Monte of Argentina. The result showed that seedling emergence of $P$. ligularis was higher in treatments with bare soil than in soil covered by crusts, and also in those with watering to field capacity. Mean emergence time was higher in treatments with bare soil and watering to field capacity. Seedling biomass also showed significant differences between treatments. These results suggest that biological soil crusts dominated by mosses do not promote $P$. ligularis emergence, although they would not affect its survival.
\end{abstract}

Keywords: drought; field capacity; recruitment; microsites; mosses; semiarid region; Poa ligularis

Citation: Flavia Alejandra FUNK, Alejandro LOYDI, Guadalupe PETER. 2014. Effects of biological soil crusts and drought on emergence and survival of a Patagonian perennial grass in the Monte of Argentina. Journal of Arid Land, 6(6): 735-741. doi: 10.1007/s40333-014-0022-8

Biological soil crusts cover a large portion of the arid and semiarid regions of the world. They have low moisture requirements and high tolerance to extreme temperatures and light, which allows them to survive under conditions that limit growth in vascular plants (Belnap, 2003). Biological crusts typically consist of a combination of organisms such as algae, fungi, lichens, mosses, cyanobacteria and heterotrophic organisms that are intimately interrelated (Johansen, 1993; Belnap et al., 2001; Serpe et al., 2006; Langhans et al., 2009).

Biological crusts have an important ecological role in ecosystems as their presence significantly changes the physical and chemical characteristics of the soils (Belnap et al., 2001). In arid and semiarid regions the crusts increase soil stability by binding soil particles together and protecting the surface from water and wind erosion (Belnap and Gardner, 1993; Johansen, 1993; Zhang et al., 2006). Soil crusts can cause changes in soil surface roughness, texture, infiltration and temperature (Belnap, 1994; Evans and Johansen, 1999; Belnap et al., 2001). Additionally, they increase (1) fertility through carbon and nitrogen fixation; (2) accumulation of other chemical elements, such as available $\mathrm{P}$ and exchangeable $\mathrm{K}$ (Harper and Pendleton, 1993; Belnap, 1994; 2002; Belnap and Harper, 1995; Evans and Johansen, 1999; Hawkes, 2003; Jafari et al., 2004); and (3) the retention of fine particles by increasing organic matter (Johansen, 1993). These changes in edaphic properties produced by

*Corresponding author: Alejandro LOYDI (E-mail: aloydi@criba.edu.ar)

Received 2013-10-20; revised 2013-12-27; accepted 2014-02-04

(C) Xinjiang Institute of Ecology and Geography, Chinese Academy of Sciences, Science Press and Springer-Verlag Berlin Heidelberg 2014 
crusts might affect the germination, establishment and fitness of vascular plants (Belnap et al., 2001). In this regard, biological crusts may influence several characteristics of vascular plant communities, such as, plant density and size, species composition and community structure (Belnap, 2006). Generally, changes in soil characteristics may enhance the reproduction of pioneer plants species (Langhans et al., 2009). There have been varied results regarding the influence of the crust on the establishment and cover of vascular plants. These results may be positive, inhibitory or have no effect over vegetation (During and Van Tooren, 1990; Belnap et al., 2001). While several studies indicate that biological soil crusts affect germination, the actual mechanisms remain unknown (Belnap, 2006). Moreover, under the same climate, temperature and moisture conditions, biological crusts differ from adjacent bare soil (Verrecchia et al., 1995; Belnap et al., 2001; Warren, 2001). Thus, crusts affect seed germination through changes in temperature and moisture, which are the environmental conditions that primarily influence the inhabitation and metabolism of seeds (Bradford, 1995; Baskin and Baskin, 1998).

In the Monte Rionegrino the biological crusts are principally dominated by moss. They cover most of inter-shrub spaces in areas of low grazing intensity, where trampling by livestock is reduced. The objective of this study is to evaluate the effect of biological crust cover on water lost from soil surface and to determine the effect of biological soil crusts on seed emergence, survival and seedling growth of a native perennial grass under drought and watering to field capacity regimes.

\section{Materials and methods}

Poa ligularis Nees. ex Steud. is widely distributed in the area, and was part of the pristine grassland communities in the Monte eco-region of Argentina (Gallego et al., 2004). Poa ligularis seeds are $<2 \mathrm{~mm}$ and their pilus determines the formation of large seed aggregations that are easily moved by wind (Aguiar and Sala, 1997). It is one of the dominant perennial grass species in the arid ecosystems of Patagonia and it is one of the species most preferred by herbivores (Correa, 1978). Grazing tends to decrease its cover and frequency and change its aggregation pattern, probably due to the lack of optimal sites for recruit- ment as a result of trampling (Peter et al., 2013).

The Monte eco-region is characterized by a transition sub-temperate dry climate, with warm summers (mean temperature of $21^{\circ} \mathrm{C}$ ) and mild winters (mean temperature of $7^{\circ} \mathrm{C}$ ). Average annual precipitation is between 200 and $350 \mathrm{~mm}$, with high intra-annual variability (Bran et al., 2000). The climate is windy, especially in spring and summer, which contributes to the soil moisture deficit. Vegetation is a shrubland steppe, with an herbaceous stratum of predominantly winter-growing grasses.

The experiment was conducted under greenhouse conditions with four treatments: pots with biological crusts and field capacity (C-FC); pots with biological crusts and drought (C-D); pots with bare soil and field capacity (BS-FC); and pots with bare soil and drought (BS-D). Soil and biological crusts were collected from natural field sites in the Monte Rionegrino, located at Adolfo Alsina department in Río Negro province, Argentina $\left(40^{\circ} 40^{\prime} \mathrm{S}, 64^{\circ} 10^{\prime} \mathrm{W}\right)$, during the winter of 2010 . Biological crust samples were collected using a cylindrical soil sampler of 10-cm diameter and 5-cm depth. Samples were place into $900 \mathrm{~cm}^{3}$ circular pots with $10-\mathrm{cm}$ diameter, filled with soil from the area and were placed in the greenhouse. The biological crusts were distributed over the entire surface of the pots, covering $>90 \%$ of its surface in all pots. Crusts are composed of two species of mosses: Syntrichia princeps (De Not.) Mitt. and Ceratodon purpureus (Hedw.) Brid., covering $70 \%$ and $30 \%$ respectively. In addition, seeds of $P$. ligularis were collected in the same area including at least 20 different mother plants during December 2008 and stored until the start of the experiment.

The experiment was completely randomized for evaluating the effect of biological crust coverage ( $k=2$, with and without biological crusts) and soil moisture $(k=2$, field capacity and drought). For the treatment with crusts, the soil in the pots was covered with biological soil crusts, while pots without crusts were only filled with soil. Pots were weighted and watered to field capacity or to half field capacity (drought treatment) every 48 hours. Field capacity was determined by watering the pot until the soil was saturated, allowing them to drain for 48 hours. After this, the weight of each pot was recorded. In order to establish the amount of water used in treatments at field capac- 
ity and under drought, a subset of pots was oven dried $\left(105^{\circ} \mathrm{C}\right)$ and the moisture content (grams of water per pot) was determined by the gravimetric method. In this way, a fixed weight was assigned to each pot corresponding to its hydric content, according to each treatment. Each treatment combination had 10 replicates, totalling 40 experimental units. In each pot 40 seeds of $P$. ligularis were sown. Prior the experiment, we tested $P$. ligularis germination power by placing 20 seeds of $P$. ligularis in glass Petri dishes $(6-\mathrm{cm}$ in diameter) containing filter paper saturated with water $(n=4)$. Seeds were incubated in a germination chamber at $20^{\circ} \mathrm{C}$ with a photoperiod of 12 hours for one month. The percentage of seed germination under these conditions was $40 \%$. In addition, eight pots without any seed were used as controls and were maintained at field capacity in order to verify the absence of seeds of $P$. ligularis in the soil or biological crusts.

For a period of eight weeks, all emerged seedlings were counted and identified weekly. Weekly emergence was measured for determining the mean emergence time (MET) in all treatments. We used the MET as a modification of the mean germination time and it was calculated as:

$$
M E T=\sum_{i=1}^{t} \frac{n_{i} t_{i}}{N} .
$$

Where $n_{i}$ is the number of seedlings that emerge within successive intervals of time, $t_{i}$ is the time between the beginning of the experiment and the end of the interval being measured and $N$ is the total number of seedlings (Deines et al., 2007). All seedlings were preserved in the pots for 35 days and then they were harvested. No seedling mortality was observed during this period. For each harvested plant, we measured leaf number, plant height and seedling biomass. Additionally, each pot was weighed on the counting date and then $48 \mathrm{~h}$ afterwards, recording its water loss. With these data, we evaluated the effect of ground cover on soil moisture loss.

All data were analyzed using two-way ANOVA, except the data of MET that was analyzed using one-way ANOVA because there was a significant interaction between treatments. The data of emergence and MET were previously transformed to natural logarithms and the leaf number, plant height and seedling biomass to arcsine-square root, to meet normality requirements. Means were compared using Tukey HSD tests. All statistics were performed with the R basic program package (R Development Core Team, 2009).

\section{Results}

Water loss through evapotranspiration showed slight differences in regard to cover by crusts or bare soil, but they were not significant. However, a higher loss of water was observed from the pots at field capacity $(P<0.001)$ (Table 1).

Emergence of seedlings was higher in treatments with bare soil than in pots with biological crusts $(P<0.01)$ (Fig. 1; Table 1). It was also higher in pots at field capacity $(P<0.001)$, without showing any differences between those having the surface covered with crusts or bare soil (Fig. 1; Table 1). In the bare soil treatments, emergence was $15.5 \% \pm 3.6 \%$, whereas in the treatments with biological crusts it was only $9.4 \% \pm 3.63 \%$. Similarly, in the pots that were at field capacity, $21.75 \% \pm 3.4 \%$ of the seedlings emerged; whereas in pots under drought conditions only $3.12 \% \pm 1.7 \%$ of the seedlings emerged. The control pots did not show any seedling of $P$. ligularis during the time of the experiment.

The MET showed significant differences between treatments $\left(F_{(3,19)}=50.93, P<0.001\right)$. No differences were found between pots at field capacity with and

Table 1 Mean values of all parameters measured during the experiment in different treatments

\begin{tabular}{|c|c|c|c|c|c|c|}
\hline Variable & $\mathrm{C}$ & BS & $P$ & $\mathrm{FC}$ & $\mathrm{D}$ & $P$ \\
\hline Emergence (seedling/pot) & $3.75 \pm 1.45$ & $6.2 \pm 1.22$ & 0.013 & $8.7 \pm 1.36$ & $1.25 \pm 0.68$ & $<0.001$ \\
\hline Water loss (g water) & $30 \pm 2.77$ & $28 \pm 2.74$ & 0.856 & $38 \pm 2.64$ & $20 \pm 0.63$ & $<0.001$ \\
\hline Height (cm/seedling) & $17.4 \pm 1.78$ & $21.03 \pm 1.25$ & 0.117 & $20.1 \pm 1.36$ & $17.79 \pm 1.40$ & 0.269 \\
\hline Leaf number & $5.29 \pm 0.62$ & $5.27 \pm 0.35$ & 0.677 & $5.7 \pm 0.35$ & $3.9 \pm 0.36$ & 0.013 \\
\hline Survival (\%) & $74.26 \pm 7.40$ & $75.71 \pm 7.32$ & 0.333 & $70.93 \pm 5.00$ & $81.76 \pm 13.91$ & 0.187 \\
\hline Biomass (mg/seedling) & $11.48 \pm 2.37$ & $11.47 \pm 1.78$ & 0.599 & $13.69 \pm 1.50$ & $4.82 \pm 1.14$ & 0.005 \\
\hline
\end{tabular}

Note: C, biological crust; BS, bare soil; FC, field capacity; D, drought. Mean \pm SE. 


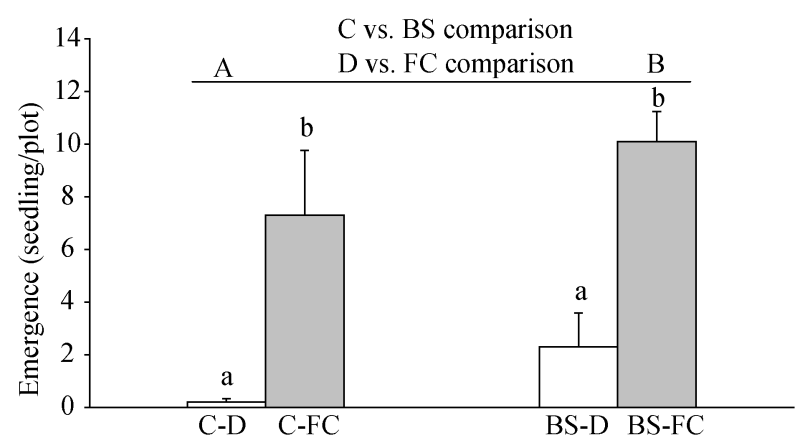

Fig. 1 Number of emerged seedlings per pot in the different treatments. Data are mean $\pm S E$. Different letters indicate significant differences among means $(P<0.05)$. C, biological crust; BS, bare soil; D, drought; FC, field capacity.

without biological crusts on the surface. However, the MET was significantly lower than the other two treatments. Under drought conditions the pots with bare soil showed a lower MET than those with crusts. In the pots at field capacity, with or without biological crust, all counted seedling emerged during the second and third weeks of the experiment. For the treatments with bare soil and drought conditions, we also registered seedling during the third and fourth weeks. While, between the sixth and seventh weeks, only seedlings in the pots with crusts and drought conditions were registered (Fig. 2).

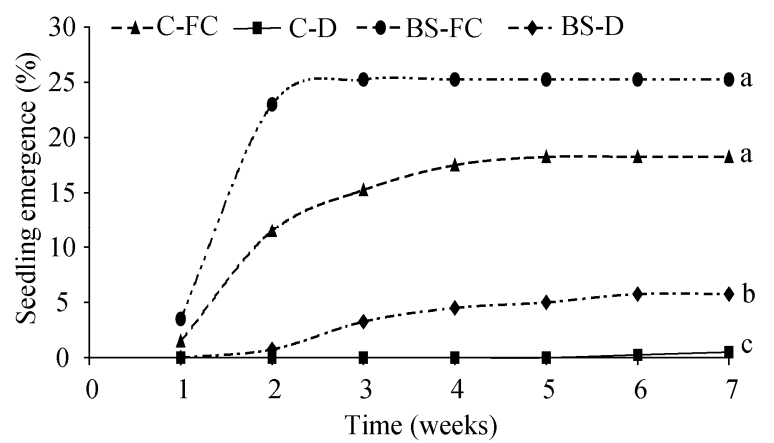

Fig. 2 Effect of treatments on the mean emergence time (MET). Different letters indicate significant differences among means $(P<0.05)$ in MET. C, biological crust; BS, bare soil; D, drought; FC, field capacity.

Seedling biomass in treatments at field capacity was higher than in those under drought conditions $(P<0.05)$, although there were no significant differences with or without cover of biological crusts (Table 1; Fig. 3). While plant heights showed no differences among treatments, a larger number of leaves was found in seedlings growing in treatments at field capacity $(P<0.01)$ (Table 1 ; Fig. 3 ). There were no significant differences in seedling survival between any treatments during the experiment (Table 1).
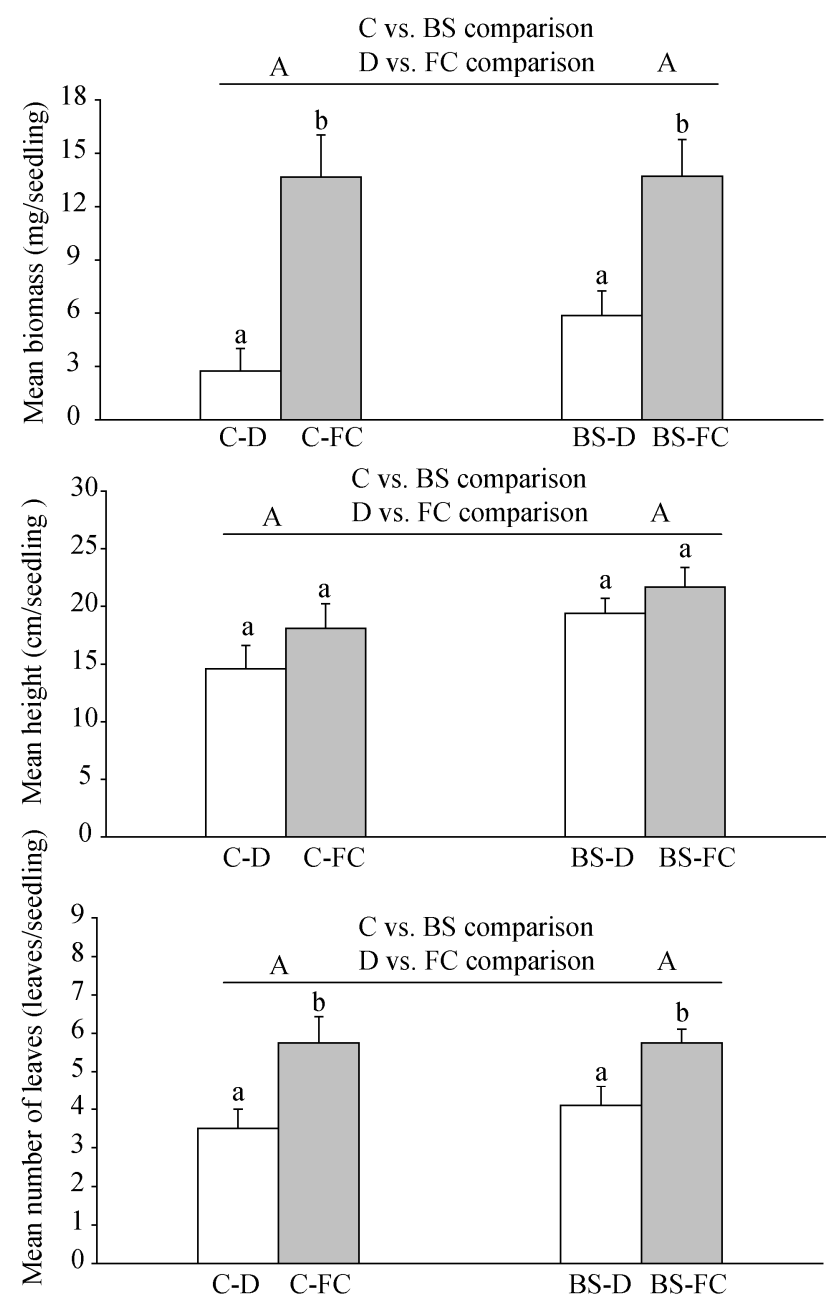

Fig. 3 Mean biomass, mean height and mean number of leaves per seedlings in different treatments. Data are mean \pm SE. Different letters indicate significant differences among means $(P<0.05)$ C, biological crust; BS, bare soil; D, drought; FC, field capacity.

\section{Discussion}

The results obtained in our study have shown a negative effect of biological soil crusts on the emergence of Poa ligularis compared to bare soil surface, but biological crusts did not affect seedling growth once they emerged. Overall, the main effect affecting seedling emergence was the watering treatments. Since biological crust did not affect soil water content, this also did not affect germination. However, in dry conditions, the presence of a biological crust lengthened the emergence time of $P$. ligularis (Fig. 2), which may affect seedling establishment.

Some authors have found negative effects of biological crusts on seedling emergence of native species (Eldridge et al., 2000; Prasse and Bornkamm, 2000; Sedia and Ehrenfeld, 2003; Jeschke and Kiehl, 2008) 
and non-native species (Larsen, 1995; Kaltenecker et al., 1999), but this effect seems to vary according to plant functional groups, being annual species positively affected or not affected by the presence of biological crusts, whereas the establishment of perennial species is usually inhibited by crust cover (Langhans et al., 2009). Negative effects seem to be stronger for grass species (Serpe et al., 2006; Langhans et al., 2009).

In arid and semiarid environments, such as in the Monte Rionegrino, it is very common to find a spatial heterogeneity in the distribution of vegetation and resources such as water, nutrients and organic matter. This heterogeneity is particularly attributed to the presence of biological soil crusts (West, 1990; Belnap et al., 2001). In several ecosystems authors have observed negative correlations between the vegetation cover and the presence of different types of crusts (Serpe et al., 2006). Savory (1988) proposed that the latter are those that limit the vegetation cover through changes in soil microtopography and the flow of water and nutrients, affecting the distribution of resources and promoting the development of islands of vegetation (Deines et al., 2007). Also, the biological crusts may contribute to the development of the pattern of the vegetation patches through its effect on seed germination and seedling establishment (Deines et al., 2007). However, it is also possible that biological crusts just colonize places that are not occupied by vascular plants. In the latter case the vegetation cover did not correlate with the cover of crusts (Kleiner and Harper, 1972, 1977; Anderson et al., 1982; Jeffries and Klopatek, 1987; Beymer and Klopatek, 1992). Other studies have shown a positive correlation between plant cover and biological crust presence (Dadlich et al., 1969; Graetz and Tongway, 1986; Carleton, 1990; Lesica and Shelley, 1992; Ladyman and Muldavin, 1994). The positive effect of the crusts may be the result of better moisture conditions created by the crusts, better availability of nutrients and reduced predation (During and Van Tooren, 1990; Belnap and Harper, 1995). However, most of these positive results were founded in woodlands or grasslands, in opposition with the semi-arid Monte eco-region. Different climatic conditions and composition of the biological crusts may be crucial to the effect of the biological crust on seedling establishment and some of the negative effects described here could be related to our study area (i.e. semi-desert).

In many cases these negative effects were related to seed traits, such as seed size (Zamfir, 2000; Sedia and Ehrenfeld, 2003; Li et al., 2008). If the seeds were small they were more likely to fall through spaces in the moss or into small depressions where humidity was higher and promoted germination (Serpe et al., 2006; Langhans et al., 2009; Burmeier et al., 2010). The combination of the shape of the seeds and the morphological characteristics of the crusts may determine if the crusts have suitable sites for germination or inhibition (Li et al., 2008). Although the seeds of $P$. ligularis were randomly dispersed on the surface of the pots in all the treatments, it is likely that in more natural settings they may tend to be located in cavities or in cracks between biological crusts due to the micro-relief of the seeds. This may be a critical point since biological crusts may reduce penetration of grass roots (Deines et al., 2007), although this effect may vary depending on the species of grasses. Thereby, although the seeds may eventually germinate in the crusts, their establishment and survival can be very restricted (Deines et al., 2007).

We found that the development of $P$. ligularis, in terms of seedling biomass and number of leaves, was better in the treatments at field capacity. These results are consistent with those found by Langhans et al. (2009), where the continuous availability of water in the treatment without crusts on the surface enhanced the survival of seedlings of the native species studied. Biological crusts prevent moisture from reaching the surface for a long time after a rain event, more than the bare soil (Belnap et al., 2001), due to a reduction on the infiltration rate (Belnap, 2006). Although this does not affect the germination of the seeds falling on the surface of the crust, it could influence the status of the seed moisture found in or under the crust. Despite this, in our study, pots with biological crusts did not retain a higher proportion of water compared to the pots with bare soil.

The effect of biological crusts on the germination of seeds is very complex, and varies with the composition and structure of the biological crusts and vascular plants (Maestre et al., 2011). The crusts have more significant and negative effects in the annual and perennial plants that do not have self-burying mechanisms, as they require some kind of disturbance that 
alters the soil surface in order to germinate (Belnap et al., 2001). This effect might be one of the reasons for the lower emergence in P. ligularis when they were sown on the biological crust.

\section{Conclusion}

The effects of biological crusts on the emergence and growing of vascular plants are controversial, because it is difficult to generalize the results, since response may change when different plant functional groups or ecosystem types are considered. In our study, biological crusts dominated by mosses reduced the emergence and emergence time of $P$. ligularis. However, the subsequent growing of the seedlings was not affected by the presence of the biological crusts, indicating that the presence of crust affects only the initial phases of establishment of $P$. ligularis.

\section{Acknowledgements}

This work was supported by the National Scientific and Technical Research Council (PIP 112-200801-01046). We thank Rosemary SCOFFIELD for English corrections.

\section{References}

Aguiar M R, Sala O E. 1997. Seed distribution constrains the dynamics of the Patagonian steppe. Ecology, 78(1): 93-100.

Anderson D C, Harper K T, Holmgren R C. 1982. Factors influencing development of cryptogamic soil crusts in Utah deserts. Journal of Range Management, 35(2): 180-185.

Baskin C C, Baskin J M. 1998. Seeds, Ecology, Biogeography, and Evolution of Dormancy and Germination. San Diego: Academic Press, 666.

Belnap J, Gardner J S. 1993. Soil microstructure in soils of the Colorado Plateau the role of the cyanobacterium Microcoleus vaginatus. Great Basin Naturalist, 53(1): 40-47.

Belnap J. 1994. Potential role of cryptobiotic soil crusts in semiarid rangelands. In: Monsen S B, Kitchen S G. Proceedings Ecology and Management of Arid Rangelands. General Technical Report INT-GTR. Ogden, Utah: USDA Forest Service, 179-185.

Belnap J, Harper K T. 1995. Influence of cryptobiotic soil crusts on elemental content of tissue of two desert seed plants. Arid Land Research and Management, 9(2): 107-115.

Belnap J, Prasse R, Harper K T. 2001. Influence of biological soil crusts on soil environments and vascular plants. In: Belnap J, Lange O L. Biological Soil Crusts: Structure, Function, and Management. Berlin: Springer-Verlag, 281-299.

Belnap J. 2003. Biological soil crusts in deserts: a short review of their role in soil fertility, stabilization, and water relations. Algological Studies, 109(1): 113-126.
Belnap J. 2006. The potential roles of biological soil crusts in dryland hydrologic cycles. Hydrological Processes, 20(15): 3159-3178.

Beymer R J, Klopatek J M. 1992. Effects of grazing on cryptogamic crusts in pinyon-juniper woodlands in Grand Canyon National Park. American Midland Naturalist, 127: 139-148.

Bradford K J. 1995. Water relations in seed germination. In: Kiegel J, Galili G. Seed Development and Germination. New York: Marcel Dekker Incorporation, 351-396.

Bran D, Ayesa J, López C. 2000. Rio Negro ecological regions. Technical Communication $\mathrm{N}^{\circ} 59$, Natural Resources Research Area, INTA EEA S. C. de Bariloche.

Burmeier S, Eckstein R L, Otte A, et al. 2010. Desiccation cracks act as natural seed traps in flood-meadow systems. Plant and Soil, 333(1-2): 351-364.

Callaway R M, Walker L R. 1997. Competition and facilitation: a synthetic approach to interactions in plant communities. Ecology, 78(7): 1958-1965.

Carleton T J. 1990. Variation in terricolous bryophyte and macrolichen vegetation along primary gradients in Canadian boreal forests. Journal of Vegetation Science, 1(5): 585-584.

Correa M N. 1978. Patagonian Flora. INTA Scientific Collection, Part III Volume VIII. Buenos Aires: National Institute of Agricultural Technology.

Dadlich K S, Varma A K, Venkataraman G S. 1969. The effect of Calothrix inoculation on vegetable crops. Plant and Soil, 31(2): 377-379.

DeFalco L A, Detling J K, Tracy C R, et al. 2001. Physiological variation among native and exotic winter annual plants associated with microbiotic crusts in the Mojave Desert. Plant and Soil, 234(1): 1-14.

Deines L, Rosentreter R, Eldridge D J, et al. 2007. Germination and seedling establishment of two annual grasses on lichen-dominated biological soil crusts. Plant and Soil, 295(1-2): 23-35.

During H J, Van Tooren B F. 1990. Bryophyte interactions with other plants. Biological Journal of the Linnean Society, 104(1-3): 79-89.

Eldridge D J, Semple W S, Koen T B. 2000. Dynamics of cryptogamic soil crusts in a derived grassland in south-eastern Australia. Austral Ecology, 25(2): 232-240.

Evans R D, Johansen J R. 1999. Microbiotic crusts and ecosystem processes. Critical Reviews in Plant Sciences, 18 (2): 183-225.

Gallego L, Distel R A, Camina R, et al. 2004. Soil phytoliths as evidence for species replacement in grazed rangelands of central Argentina. Ecography, 27(6): 725-732.

Graetz R D, Tongway D J. 1986. Influence of grazing management on vegetation, soil structure and nutrient distribution and the infiltration of applies rainfall in a semiarid chenopod shrubland. Austral Ecology, 11(4): 347-360.

Harper K T, St. Clair L L. 1985. Cryptogamic soil crusts on arid and semiarid rangelands in Utah: effects on seedling establishment and soil stability. Final Report Bureau of Land Management, Utah State Office, Salt Lake City.

Harper K T, Pendleton R L. 1993. Cyanobacteria and cyanolichens can they enhance availability of essential minerals for higher plants? Great Basin Naturalist, 53 (1): 59-72.

Hawkes C V. 2003. Nitrogen cycling mediated by biological soil crusts 
and arbuscular mycorrhizal fungi. Ecology, 84(6): 1553-1562.

Jafari M, Tavili A, Zargham N, et al. 2004. Comparing some properties of crusted and uncrusted soils in Alagol Region of Iran. Pakistan Journal of Nutrition, 3(5): 273-277.

Jeffries D L, Klopatek J M. 1987. Effects of grazing on the vegetation of the blackbrush association. Journal of Range Management, 40: 390-392.

Jeschke M, Kiehl K. 2008. Effects of a dense moss layer on germination and establishment of vascular plants in newly created calcareous grasslands. Flora, 203(7): 557-566.

Johansen J R. 1993. Cryrtogamic crusts of semiarid and arid lands of North America. Journal of Phycology, 29: 140-147.

Kaltenecker J H, Wicklow-Howard M, Pellant M. 1999. Biological soil crusts: natural barriers to Bromus tectorum L. establishment in the northern Great Basin, USA. In: Eldridge D, Freudenberger D. Proceeding VI International Rangeland Congress. Queensland, Qld. The Congress, 109-111.

Kleiner E F, Harper K T. 1972. Environment and community organization in grasslands of Canyonlands National Park. Ecology, 53: 229- 309.

Kleiner E F, Harper K T. 1977. Soil properties in relation to cryptogamic groundcover in Canyonlands National Park. Journal of Range Management, 30 (3): 202-205.

Ladyman J A R, Muldavin E. 1994. A study of the terricolous cryptogam and other ground cover in low disturbance pinyon-juniper woodlands in New Mexico. USDA Forest Service, Albuquerque, NM.

Langhans T M, Storm C, Schwabe A. 2009. Biological soil crusts and their microenvironment: Impact on emergence, survival and establishment of seedlings. Flora, 204(2): 157-168.

Larsen K D. 1995. Effects of microbiotic crusts on the germination and establishment of three range grasses. PhD Dissertation. Boise: Boise State University.

Lesica P, Shelly J S. 1992. Effects of cryptogamic soil crust on the population dynamics of Arabis fecunda (Brassicaceae). American Midland Naturalist, 128: 53-60.

Li X R, Song W M, Gao Y P, et al. 2008. Effects of crust and shrub patches on runoff, sedimentation, and related nutrient $(C, N)$ redistribution in the desertified steppe zone of the Tengger Desert, Northern China. Geomorphology, 96(1): 221-232.

Maestre F T, Bowker M A, Cantón Y, et al. 2011. Ecology and functional roles of biological soil crusts in semi-arid ecosystems of Spain. Journal of Arid Environments, 75(12): 1282-1291.

Pendleton R L, Warren S D. 1995. Effects of cryptobiotic soil crusts and
VA mycorrhizal inoculation on growth of five rangeland plant species. In: West N E. Fifth International Range Congress. Salt Lake City: Society for Range Management, 436-437.

Peter G, Funk F A, Torres Robles S S. 2013. Responses of vegetation to different land-use histories involving grazing and fire in the North-east Patagonian Monte, Argentina. The Rangeland Journal, 35 (3): 273-283.

Prasse R, Bornkamm R. 2000. Effect of microbiotic soil surface crusts on emergence of vascular plants. Plant Ecology, 150(1-2): 65-75.

R Development Core Team. 2009. R: A Language and Environment for Statistical Computing. Vienna: R Foundation for Statistical Computing.

Savory A. 1988. Holistic Resource Management. Covelo: Island Press, 564.

Sedia E G, Ehrenfeld J G. 2003. Lichens and mosses promote alternate stable plant communities in the New Jersey Pinelands. Oikos, 100(3): 447-458.

Serpe M D, Orm J M, Barkes T, et al. 2006. Germination and seed water status of four grasses on moss-dominated biological soil crusts from arid lands. Plant Ecology, 185(1): 163-178.

Serpe M D, Zimmerman S J, Deines L, et al. 2008. Seed water status and root tip characteristics of two annual grasses on lichen-dominated biological soil crusts. Plant and Soil, 303(1-2): 191-205.

Verrecchia E, Yair A, Kidron G J, et al. 1995. Physical properties of the psammophile cryptogamic crust and their consequences to the water regime of sandy soils, northwestern Negev Desert, Israel. Journal of Arid Environments, 29(4): 427-437.

Warren S D. 2001. Influence of biological soil crusts on arid land hydrology and soil stability. In: Belnap J, Lange O L. Biological Soil Crusts: Structure, Function, and Management. Berlin: Springer, 349-362.

West N E. 1990. Structure and function of microphytic soil crusts in wildland ecosystems of arid to semi-arid regions. Advances in Ecological Research, 20: 179- 223.

Zamfir M. 2000. Effects of bryophytes and lichens on seedling emergence of alvar plants: evidence from greenhouse experiments. Oikos, 88(3): 603-611.

Zhang Y M, Wang H L, Wang X Q, et al. 2006. The microsturcture of microbiotic crust and its influence on wind erosion for a sandy soil surface in the Gurbantunggut Desert of Northwestern China. Geoderma, 132(3): 441-449. 